\title{
Role of Mentoring in Civil-Structural Engineering: Two Greats Who Touched Many- Sozen and Ersoy
}

\author{
F Necati Catbas* \\ Civil, Environmental and Construction Engineering (CECE) Department, University of Central Florida, USA
}

*Corresponding author: F Necati Catbas, Professor and Founding Director, Civil Infrastructure Technologies for Resilience and Safety (CITRS), University of Central Florida, USA.

Received Date: June 23, 2019

Published Date: July 26, 2019

\section{Short Communication}

Is Civil-Structural engineering an art, a science, or a technology that brings scientific knowledge, mainly from physics and mathematics, to work seamlessly in nature, in examples such as bridges, buildings and dams? The short communication entitled "Civil-Structural Engineering: Artist to Technician to Scientist" by Aktan [1] provides some valuable insights related to this subject. It is discussed that society started to consider engineering not as art but as applied science after the Second World War. In the new millennium, civil engineers need to be far more proactive when dealing with complex systems, especially the intersections, interactions, and interdependencies between different infrastructures and the built environment, such as in smart cities. Regardless of how anyone perceives this great profession, civil-structural engineering is also a profession where mentorship is essential, whether in practice or in academia. A good Master-Apprentice relationship is vital not only for professional growth but also for widening the collective understanding of our profession, thus broadening our roles and responsibilities. I would like to share some of my personal experiences, particularly those in academia; but first, some basic definitions. The dictionary definition of the word mentor is "a wise and trusted counselor or teacher." While the origin comes from one of the great works of literature by Homer, we often mix the use of the words mentor and advisor. In academic life, the act of mentoring goes beyond faculty advising, which can be limited to guiding academic progress. One of the most rewarding experiences one personally can have in professional life is mentoring other engineers or engineering students. Mentoring is a professional relationship with a special personal aspect that develops, evolves, and hopefully enriches the academic, professional, and personal experiences of both the mentor and the mentee. The styles of mentoring may vary, and each mentoring relationship should be tailored to the junior engineer's goals, needs, learning styles, and willingness to be mentored. There are a number of great publications on being a mentor in general and in civil engineering in particular; here, I would like to share my personal views and experiences (Figure 1).

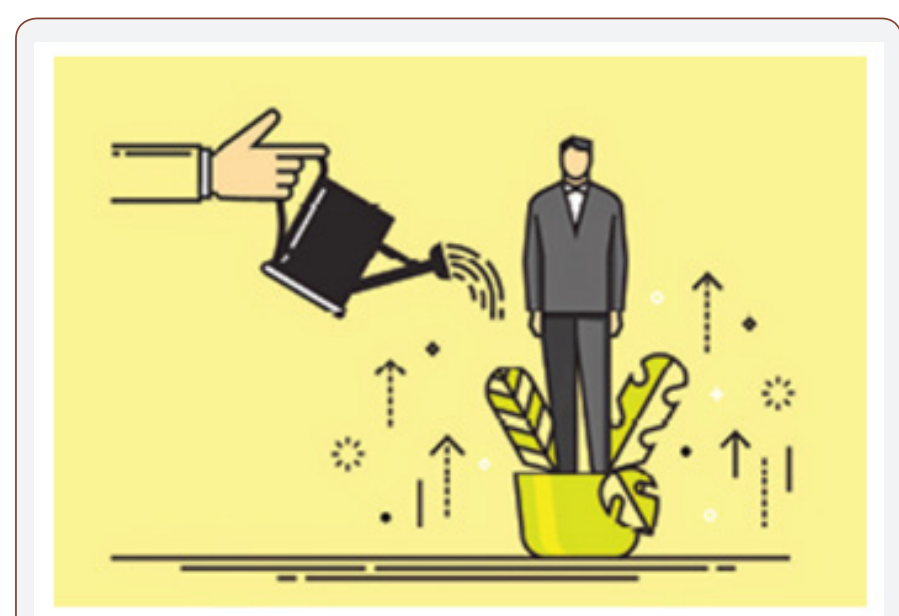

Figure 1: Mentoring Others Grow (Illustration: Shutterstock).

In the civil-structural engineering profession, and academia, we have the great responsibility of educating and mentoring our students, and in my case, preparing future civil-structural engineers, especially the doctoral students in graduate programs that are expected to be leaders in their fields. It is to those doctoral students, who as individuals are my closest students, colleagues, friends, and mentees, that I owe my best support during their time with me, and even after, while they are establishing themselves in practice or academia. I subscribe to the belief that a university is to be a community of professors and students learning and growing together. Advising and mentoring our doctoral students, a service that we as faculty members can and should provide, in ways that both include and extend beyond the technical issues of specific subjects is of particular importance towards achieving this goal. In the high pace high-pressure lives of professionals today, there 
are many kinds of pressures, time constraints, and particular goals to achieve for our professional endeavors. How does mentoring fit into this picture? Does mentoring truly help us? My experience is that it helps us even more than expected, particularly when considering the sense of personal fulfillment and satisfaction realized when seeing your mentees succeed. I do not think that there is a single formula for being a good mentor. It requires the commitment of both the mentor and mentee and demands a kind of chemistry and understanding, which can help overcome challenges and resolve difficulties. Building a group that functions as a supportive learning community is also a critical component in mentoring students. I enjoyed and benefited from such a group as a doctoral student some years ago with my fellow students and post-doctoral associates. Shared goals, collective efforts, and fellowship help reduce pressures, enjoyably increase productivity, and develop life-long friendships. The post-doctoral students in my research group help me greatly in mentoring junior graduate and undergraduate students. In addition to holding regular weekly meetings with my advisees and mentees, I find it very useful to have social activities together from time to time. Each student has a different personal and cultural background, and such activities make the professors more approachable. While being a mentor, it might be a little challenging to provide feedback and sometimes criticism. Providing constructive criticism professionally, listening carefully, and more importantly praising their good work shows that this is done to hold them to high standards in order to help them improve. I have enjoyed the fellowship of my graduate student mentees, from whom I have also learned much. Throughout their stay as graduate students, I do my best to set examples for them so that they may also refine their understanding of the importance of social interactions in a professional setting, as well as how to learn and live values within the academic environment that we share. I think this is very important to help the graduate students make decisions in life consistent with their goals and values, to recognize their capabilities and limitations, and to make life expectations and results that match.

Later in my life as a faculty, I have had two great professors of civil-structural engineering who have greatly influenced my views towards not only the civil-structural engineering profession but also towards life in general (Figure 2). They became mentors to me unexpectedly. One of them is the late Prof. Mete Sozen (1930-2018), who had a long and distinguished civil-structural engineering career at the University of Illinois, Urbana/Champagne, and Purdue University [8]. Mete, as he would like to be called, became a wellknown figure in structural engineering when he was very young. The research he performed at the University of Illinois was of top quality. His verbal and written presentations were excellent and easy to understand. His pioneering research in earthquake engineering and reinforced concrete influenced design codes all over the world [2]. Prof. Sozen was elected to the US National Academy of Engineering in 1977 [3] and received many other awards and recognitions. He was the advisor and mentor of about 60 doctoral students, who have become leaders in their respective fields (one of them being my doctoral advisor Prof. Emin Aktan). Mete was not only a true scholar but a true intellectual. The other person that has inspired me and mentored me, even sometimes without knowing, is Prof. Ugur Ersoy, who is arguably the father of reinforced concrete in Turkey. Prof. Ersoy has received the American Concrete Institute (ACI) Honorary Member Award for his contributions in education, research, and practice that have improved reinforced concrete design and construction in Turkey, and in seismic zones around the world [4]. Prof. Ersoy is also one of the persons who have been instrumental, as a professor, department chair, founding dean, and vice president, to the success of Middle East Technical University (METU), one of Turkey's top universities, since its start (Figure 2) [9].

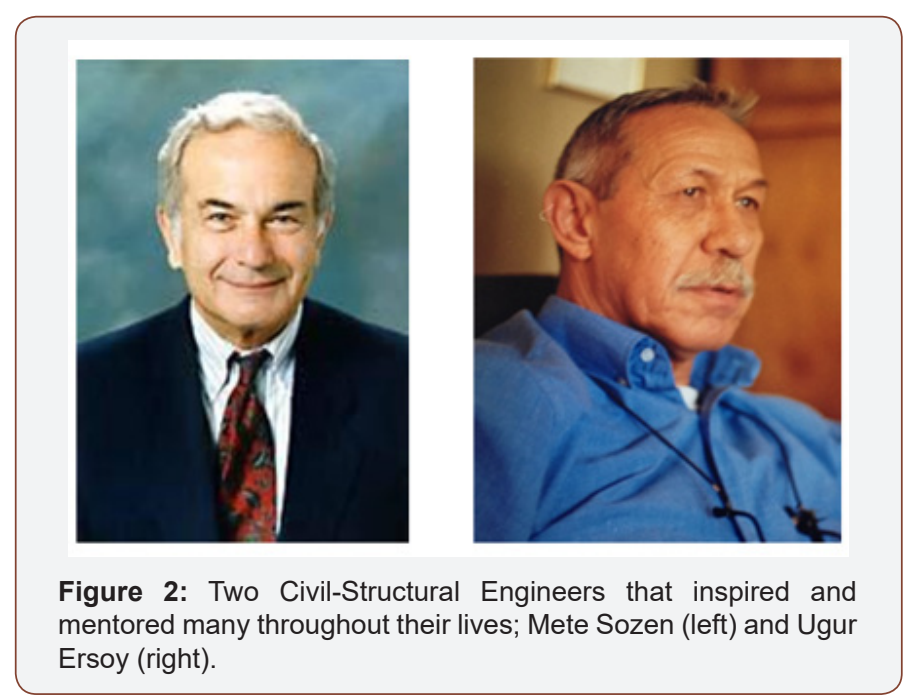

It may seem not to be too unlikely to cross paths with these two greats. First, both were advisors and mentors to my doctoral advisor and mentor, Prof. Emin Aktan. Secondly, I took courses from Prof. Mete Sozen, and my brother took courses from Prof. Ugur Ersoy. Finally, I had the privilege of spending one year with Ugur Ersoy during my sabbatical 2015-2016 in Bogazici University, which was established as Robert College in 1863, from where Sozen, Ersoy, and myself graduated in 1951, 1955, and 1991, respectively. The friendship and mentor-mentee relationship that developed over the years have not only shaped my views of engineering, but also how broad our thoughts and roles in life should be. Another great structural engineer and contemporary of Sozen and Ersoy was Dr. Fazlur R. Khan [5] (1929-1982), who is widely credited as the innovative structural engineer responsible for advancing the field of high-rise and large-scale design in the 20th century. A famous quote from Khan also captures the spirit of both Sozen and Ersoy's careers: "The technical man must not be lost in his own technology; he must be able to appreciate life, and life is art, drama, music, and most importantly, people." Sozen and Ersoy, who have remained close friends for more than half a century, would talk about politics, earthquake problems, recent books (not engineering), new trends in earthquake engineering, and many other subjects [2]. Mete Sozen was an avid reader, a rare intellect with in-depth knowledge of subjects such as politics, literature, philosophy, and history. Ugur Ersoy, who competed at professional sports (soccer and volleyball) 
before his academic career is also a writer of several storybooks, biographies, memoirs, fables, and poetry, in addition to his reinforced concrete, strength of materials, and mechanics books, which are key references in their technical engineering categories. Their mentoring, education, research, and practice reflected their broad, multidimensional views of life.

Some 600 years ago, the Renaissance symbolized the emergence of the individual. A prominentfigure of the Renaissance was Leonardo da Vinci, who made some of his most ambitious investigations in Florence, including sketches of flying machines, human anatomy, and military defense projects, and studies pertaining to mechanics, carpentry, painting, sculpting, and architecture, which today are eloquently described and immortalized in many different texts. The statue of Leonardo da Vinci, located in Piazza della Scala today, offers a solemn and austere image of the great Renaissance master and four of his favorite apprentices (Figure 3).

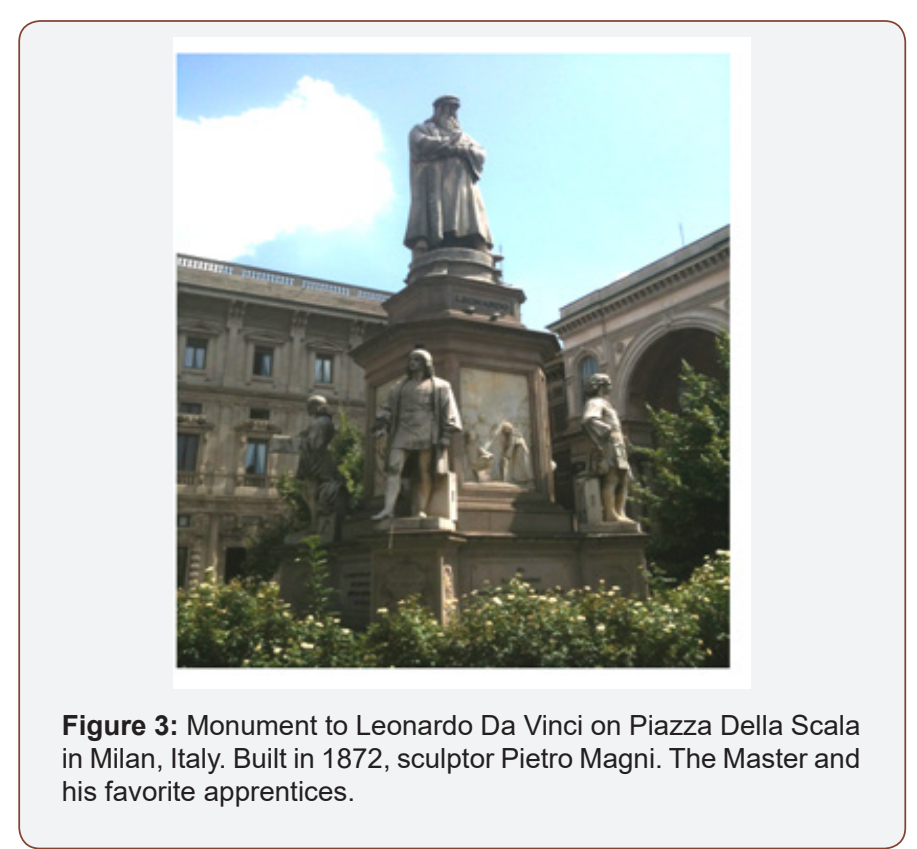

Individuals such as da Vinci, who epitomized the time, were broad thinkers whose vision encompassed the sciences, the arts, and the political forces of the day [6]. Early Renaissance artists were routinely involved in broad activities that would now be defined as engineering, where they integrated art, science, and technology with aesthetics to design some of the most creative structures for society's service that have lasted centuries. I would call Mete Sozen and Ugur Ersoy, "Renaissance Engineers," who inspired me and many others as both role models and mentors. I wish all civilstructural engineers find their life-long mentors such as these "Renaissance Engineers" who will not only help in engineering practice but also go beyond technology to appreciate life and the people that we serve through our profession.

\section{Acknowledgment}

I would like to thank my former advisors, mentors and mentees who have helped develop and shape my civil/structural engineering career especially in academia. My MS advisor Prof. Semih S. Tezcan, my doctoral co-advisor Prof. David L. Brown, and my doctoral and post-doctoral advisor/mentor Prof. A. Emin Aktan have to be acknowledged. In addition, several students some of whom have already advanced in their careers have been my mentees and some of them have also become my friends. My brother Hayati Catbas has also contributed to my career in many different ways, and also edited this paper for content. My student Kaile'a Moseley did the proof reading. I acknowledge and thank them all.

\section{Conflict of Interest}

No conflict of interest.

\section{References}

1. Aktan AE (2019) Civil-Structural Engineering: Artist to Technician to Scientist. Cur Trends Civil \& Struct Eng 3(1): 1-2.

2. Ersoy U (2019) Mete and Engineering Education.

3. NAE (1977) National Academy of Engineering.

4. ACI (2019) American Concrete Institute website.

5. Dr. Fazlur Khan "https://drfazlurrkhan.com/"

6. Akay A (2003) The renaissance engineer: educating engineers in a post9/11 world. EUR J ENG 28(2): 145-150

7. Catbas FN (2010) Mentoring Graduate Students, Faculty Focus, University of Central Florida, USA 10(2).

8. Gulkan P (2018) “Mete Sozen- Collection, Personal Remembrances," University of Illinois, USA.

9. Tankut T (1999) The Seven Colors of Ugur Ersoy-An Interview. Turkish Engineering News (in Turkish), Turkey. 